\title{
Bluetooth enables in-door mobile location services
}

\section{Thongthammachart, Saowanee; Olesen, Henning}

\section{Published in:}

Proceedings of the 57th IEEE Semiannual Vehicular Technology Conference

Publication date:

2003

Document Version

Publisher's PDF, also known as Version of record

Link back to DTU Orbit

Citation (APA):

Thongthammachart, S., \& Olesen, H. (2003). Bluetooth enables in-door mobile location services. In Proceedings of the 57th IEEE Semiannual Vehicular Technology Conference: VTC'2003 (Vol. 3, pp. Session 8H, paper 3). IEEE.

\section{General rights}

Copyright and moral rights for the publications made accessible in the public portal are retained by the authors and/or other copyright owners and it is a condition of accessing publications that users recognise and abide by the legal requirements associated with these rights.

- Users may download and print one copy of any publication from the public portal for the purpose of private study or research.

- You may not further distribute the material or use it for any profit-making activity or commercial gain

- You may freely distribute the URL identifying the publication in the public portal

If you believe that this document breaches copyright please contact us providing details, and we will remove access to the work immediately and investigate your claim 


\title{
Bluetooth Enables In-door Mobile Location Services
}

\author{
Saowanee Thongthammachart and Henning Olesen \\ Center for Tele-Information \\ Technical University of Denmark, Building 371, 2F \\ 2800 Kgs. Lyngby, Denmark \\ saowanee@cti.dtu.dk, olesen@cti.dtu.dk
}

\begin{abstract}
Several technologies can be applied to enable mobile location services, but most of them suffer from limited accuracy and availability. GPS can solve the problem of determining the location of users in most outdoor situations, but an end-user position inside a building cannot be pinpointed. Other mobile location techniques can also provide the user's position, but the accuracy is rather low. In order to improve the accuracy and make location-based services really attractive, existing approaches must be supplemented by new technologies. Wireless short-range technologies like Bluetooth could be candidates for solving these problems. This paper shows, that Bluetooth can act as a key enabler of mobile location services in an in-door environment. The advantage of Bluetooth technology is, that it can provide rather precise location data inside a building or hotspot area, while the Bluetooth terminal is connected to the network. Hence, the users will be able to obtain more detailed guidance and information on their sites of interest such as department stores, airports and other public areas.
\end{abstract}

Index Terms-Wireless, 3G, in-door positioning, Bluetooth, mobile services.

\section{INTRODUCTION}

$\mathrm{M}$ OBILE location services ${ }^{1}$ and personal navigation represent a huge potential and challenge for business players in the mobile service arena [1]. Location-based services have been identified as one of the six main service categories in studies by the UMTS Forum [2], and the estimated number of users is expected to exceed a hundred million over the next few years. Mobile location services will allow the users to find out where they are and track their friends or family members. Moreover, many more applications based on location will become available. Mobile location services will be one of the crucial tools for providing mobile users with the right service at the right time and in the right location. Actually, mobile location services based on the GSM and GPRS platform are available today, but these services are not really attractive to the end-user. Users are not willing to pay the service charge for a service with a poor quality. Mobile location services will only succeed, if the mobile service providers can offer more accurate positioning, more attractive user interfaces and appealing content, and if they can provide position information inside buildings. Part of the solution could be to complement $3 \mathrm{G}$ mobile networks with Bluetooth networks [3-5]. The advent of $3 \mathrm{G}$ networks will expand the potential of mobile location services in much the same way as the improvements in data transmission performance and mobile terminal characteristics (bigger screen, more colors, built-in camera, Bluetooth embedded). $3 \mathrm{G}$ networks provide higher data rate than GSM and GPRS networks. Therefore, rich location information can be sent via the network and, with improved terminals, multimedia user interfaces can be launched. Furthermore, the coverage area of $3 \mathrm{G}$ mobile base stations is smaller than that of GSM and GPRS and provides outdoor location information with a higher accuracy.

The biggest Japanese telecommunication operator, NTT DoCoMo, launched the first $3 \mathrm{G}$ mobile communication networks in 2001, and other operators around the world are following. In this high competition market, most of the big mobile terminal manufacturers have decided to embed Bluetooth connectivity into their mobile terminals. This will make it possible to take advantage of localization data, while Bluetooth terminals are connecting to the $3 \mathrm{G}$ mobile networks via Bluetooth access points, and the location can then be determined on a granularity level of approximately 10 meters, corresponding to the cell radius.

This paper describes not only how different location techniques work, but also what impact each technique will have on the network, the mobile terminal and the cell size. We will also discuss how wireless short-range technology like Bluetooth can provide information of location inside buildings and how to share location data over the limited range of an adhoc network. Furthermore, the benefits of complementing of $3 \mathrm{G}$ networks and Bluetooth networks will be described.

In section II, advantages and disadvantages of the existing technologies behind mobile location services will be outlined. We will then describe, in section III, the concept of mobile location services employing Bluetooth technology and how Bluetooth can enable the in-door mobile location services. In Section IV, the service scenario of complementary Bluetooth and $3 \mathrm{G}$ networks will be proposed. Finally, the conclusion and suggestions for future work will be given in section V.

'Note, that the tenm "location service" includes both location-based and location-dependent services as explain in Ref. 1. 


\section{The Existing TeChNologies BEHIND MoBile LoCATION SERVICES}

Several technologies for mobile location services are available today. All of them have their limitations; some require changes in the mobile terminal itself, whereas others require changes in the network. Multi-path propagation and line-of-sight can have a significant influence on the accuracy.

Table I shows a comparison between the most important location technologies.

TABLE I

A COMPARISON BetWeEn DiFHERENT Location TECinOlogies

\begin{tabular}{lllll}
$\begin{array}{l}\text { Positioning } \\
\text { Technology }\end{array}$ & $\begin{array}{l}\text { Mobile } \\
\text { Gencration }\end{array}$ & Accuracy & $\begin{array}{l}\text { Coverage } \\
\text { inside } \\
\text { building }\end{array}$ & $\begin{array}{l}\text { Provides } \\
\text { locations } \\
\text { inside } \\
\text { building }\end{array}$ \\
\hline Cell-ID & $2 \mathrm{G}$ & $300 \mathrm{~m}-10 \mathrm{~km}$ & Yes & No \\
Cell-ID+1 & $2 \mathrm{G}$ and $3 \mathrm{G}$ & $100-500$ & Yes & No \\
E-OTD & $2 \mathrm{G}$ & $150-500 \mathrm{~m}$ & Yes & No \\
OTDOA & $3 \mathrm{G}$ & $30 \mathrm{~m}$ & Yes & No \\
A-GPS & $2 \mathrm{G}$ and $3 \mathrm{G}$ & $5 \mathrm{~m}$ & N/A & N/A \\
Bluctooth & 2G and 3G & $10 \mathrm{~m}$ & Yes & Yes \\
\hline
\end{tabular}

\section{A. Cell-Identification (Cell-ID)}

Cell-ID is the simplest technique to determine the location of mobile terminals, but also the least accurate. When an active mobile station (MS) is connecting to a base station, then the MS is known to be located geographically within the area served by this base station. Reliable positioning therefore requires accurate maps of coverage area of the base stations. The accuracy of Cell-ID depends on the cellular network density; smaller cells provide higher accuracy. To improve the accuracy, two network radio measurements can be used with the Cell-ID. This technique is called Cell-ID++. The Cell ID and Cell-ID ++ technique can be either terminal based or network based.

\section{B. Enhanced Observed Time Difference E-OTD}

This technique provides slightly better accuracy than CellID++. The mobile station measures the arrival time of signals from three or more base stations, which must be synchronized. Base stations must be further equipped with receivers to measure the mutual time difference between the base stations. The position of the mobile station can be obtained by combining these two pieces of information in the mobile location center. E-OTD is not supported by existing mobile terminals, which will require software modifications. So, hardware needs to be added to the network and software needs to be added into the mobile terminal. Since the mobile terminal position can only be obtained by measuring the signal from at least three cell sites, this technique does not function well in rural areas.

\section{Global Positioning system (GPS)}

This method is based on the GPS satellite constellation and offers the highest accuracy. But there are still problems in making services available for users inside a building. This is because the mobile terminal requires visibility of at least 3 satellites to estimate the 2-dimensional position. To solve this problem, the network operator can provide assistance data to enable a GPS receiver to provide a position, even in a challenging environment. This is called Assisted GPS (AGPS). In this method, assisted GPS and location calculation have to be added into the network, and the mobile terminal needs a second GPS antenna, a GPS RF front-end and processing, memory and software must be added. Therefore this positioning technique has a cost impact, not only to the network operators, but also to the users.

\section{D. $3 G$ positioning}

$3 \mathrm{G}$ in principle offers the same types of positioning methods, but with some modifications, e.g. due to the use of WCDMA. Because WCDMA occupies a larger bandwidth than GSM, the accuracy is potentially higher, but complications arise due to soft hand-over and masking of weaker base stations.

\section{MOBILE LOCATION SERVICES WITH BLUETOOTH}

Bluetooth is a wireless short-range technology, often referred to as a wire replacement technology. It is designed to operate in the unlicensed ISM band at $2.4 \mathrm{GHz}$, which is available all over the world. It was developed to form a piconet by using a master/slave based MAC protocol. The specified transmitter power of a Bluetooth terminal is $1 \mathrm{~mW}$ (at 10 meter coverage area with class 3 standard), which is very suitable for mobile devices such as mobile phones or PDAs. The low power consumption of the Bluetooth module will not significantly affect the battery life of the terminal. Because Bluetooth operates in the ISM band, no license fee is required, therefore a terminal with embedded Bluetooth could be applied worldwide. The short-range characteristics of Bluetooth make it very useful for mobile location services. When a Bluetooth terminal is connecting to an access point, this also determines the location of the Bluetooth terminal within the 10-meter coverage area - without any additional localization mechanism. Due to the small coverage area of Bluetooth networks, many access points are required.

There are three types of wireless connectivity: wire replacement, ad-hoc networking [6] and infrastructure-mode networking [7]. The Bluetooth standard includes all three types of connectivity. To take advantage of the user's position, Bluetooth networks must be configured in infrastructure mode as shown in Figure 1. 


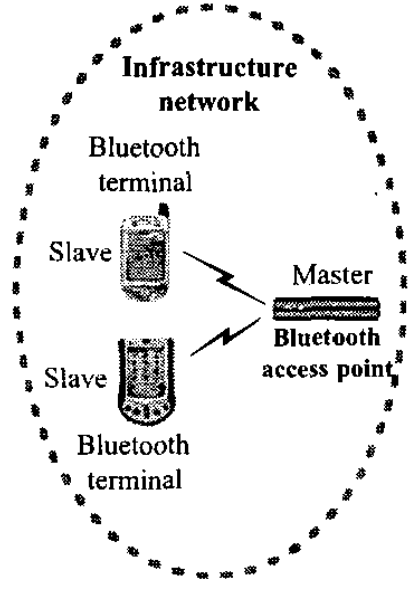

Fig 1. Infrastructure mode nctwork.

In an infrastructure mode network, the Bluetooth access point must always perform the role of master in the piconet and participating devices must operate as slaves. While Bluetooth terminals are connected to the mobile network via an access point, they can communicate with other terminals in ad-hoc mode. Therefore, Bluetooth terminals can exchange location information between each other. Also, if one of the Bluetooth terminals is equipped with another location technology, e.g. GPS, it will be able to share its location information with Bluetooth terminals in the piconet as shown in Figure 2.

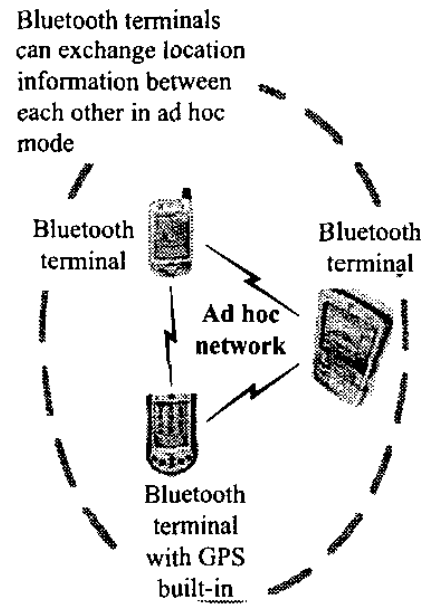

Fig. 2. Bluetooth terminals exchange location data between each other within Piconet in ad-hoc mode.

The location of mobile terminals with embedded Bluetooth can be known, if these terminals are close enough to the Bluetooth access point. The Bluetooth access point is the
Bluetooth device, that provides the interface to the mobile network. Thus, the deployment of Bluetooth access points is required. This Bluetooth fixed infrastructure is expected to be installed widely in the public area, office or home. The positioning measurement of the Bluetooth location technique is the coordination of the nearest Bluetooth fixed access point to the Bluetooth terminal. Therefore, if the Bluetooth fixed infrastructure is implemented properly, it could provide a high accuracy positioning. The cost of deploying this infrastructure might be a limiting factor, but it might be justified by other purposes as well. For the mobile terminal, the Bluetooth interface is simply an embedded chip or a plug-in module.

In this scheme, the positioning calculation unit resides in a location server instead of the mobile terminal in order to preserve the mobile terminal's battery life. The location of mobile users will be obtained by mapping the unique physical address of the Bluetooth access point, where the mobile terminal is connecting, with geographical location information in the location server. To provide a reliable location service, the system should be able to guarantee, that the mobile terminal is connected to the nearest access point and only one position has been read. Moreover, the users' location should be updated automatically, when they move from one access point to another access point. The mechanism of users' location determination is shown in Figure 3.

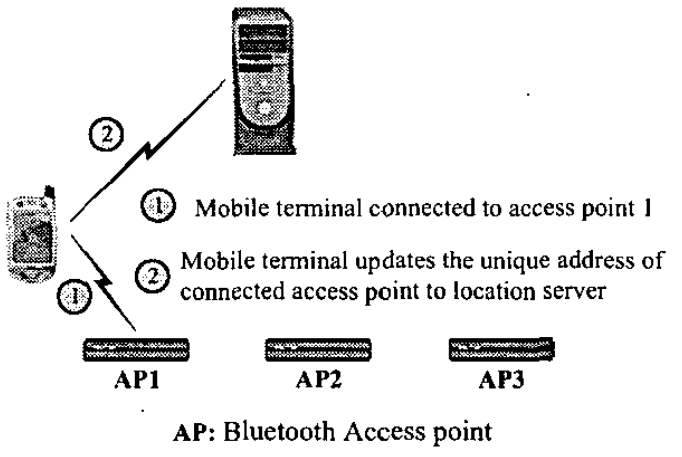

Fig. 3. User's location determination mechanism.

In Figure 3, when the mobile terminal detects, that it is connected to access point 1 (AP1), it informs the unique physical address of this access point to the location server. Therefore, the location of the connected terminal can be known by correlating the physical location of the access point with an accurate geographical map. In the case, where the mobile terminal moves from access point 1 to access point 2 or even access point 3 , the system needs some sort of handover between access points in order to provide automatic location update. Since there is no hand-over mechanism defined in the Bluetooth standard, this mechanism will need to be implemented and embedded into the Bluetooth networks. 


\section{BLUETOOTH INTEGRATED WITH 3G NETWORKS}

The combination between Bluetooth networks and $3 \mathrm{G}$ networks will enable a flexible mobile location service. This service will be available for local location services, such as a free in-door location service in department stores. It will also be available for $3 \mathrm{G}$ users, who will be able to track friends or family members inside buildings. Most users spend a considerable amount of their time inside buildings such as home and office.

Besides making in-door mobile location services available, the complementary functionality of Bluetooth and $3 \mathrm{G}$ networks could potentially reduce the unnecessary traffic on $3 \mathrm{G}$ networks. The $3 \mathrm{G}$ networks could then be used to deliver a trunk/access connection to specific locations, and Bluetooth could provide the final delivery and local network connection.

In the case of local location services, the system offers the user's location within a local area, such as a free directionfinding system for the customer in department store. The fixed access points have to be set up in that area. The service system requires accurate maps of fixed access point infrastructure to make the service reliable.

The service scenario of the combined system is shown in Fig. 4.

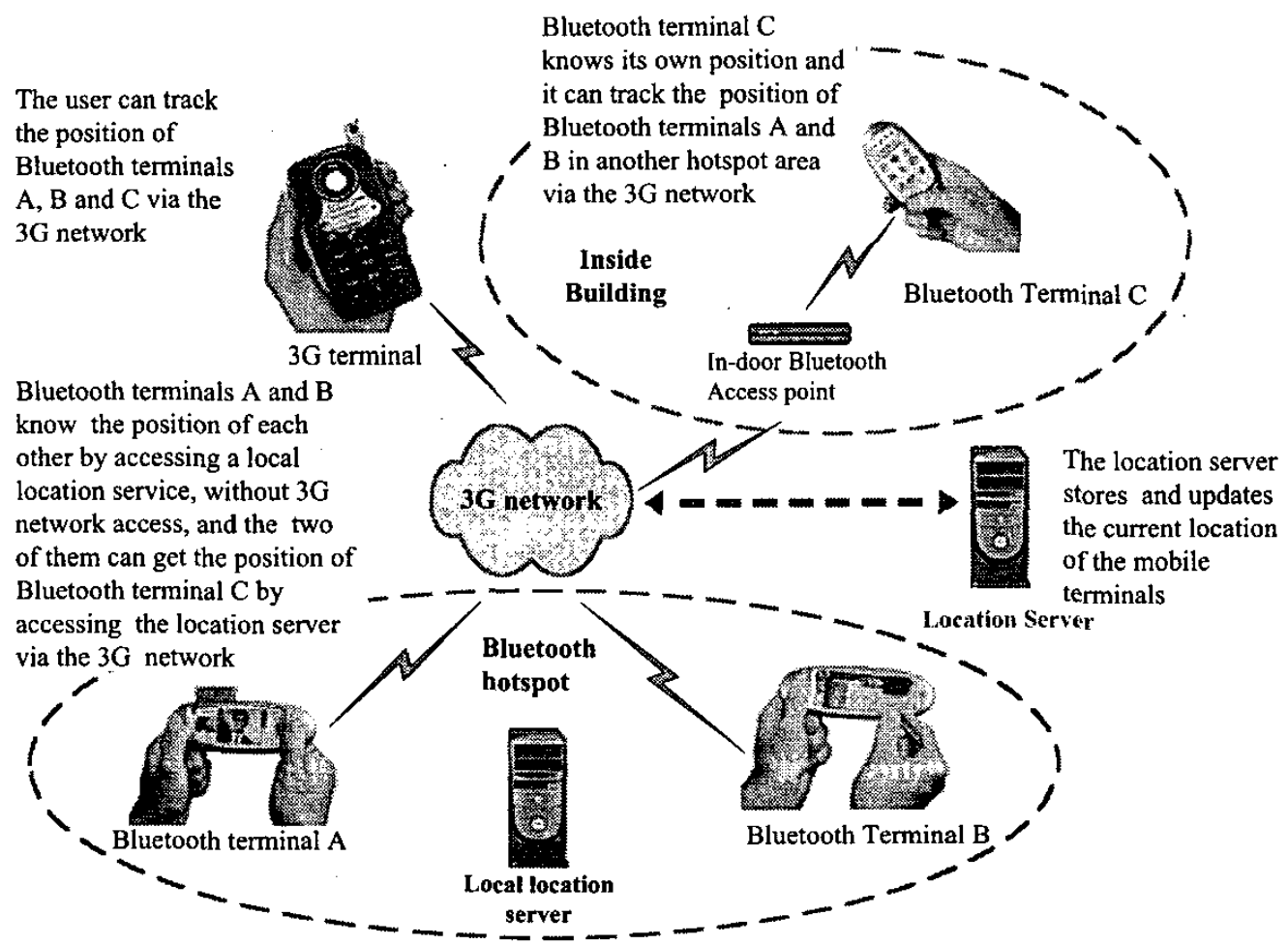

Fig. 4. Service scenario of Bluetooth and $3 \mathrm{G}$ complementary networks.

\section{CONCLUSION AND FUTURE WORK}

In this paper we have described the concept of in-door mobile location services by combining $3 \mathrm{G}$ networks and Bluetooth networks. The mobile users can obtain more detailed guidance inside buildings. They are also able to track another mobile user's position in buildings or in hotspot areas. The Bluetooth terminals in a piconet can share the location data with each other in ad-hoc mode.

This paper has only addressed the technical feasibility of indoor positioning, but it should not be forgotten, that location services always have an ethical aspect of protecting the users' privacy. Mobile users should have the right to give or not give permission to other users, who want to track their position, and implementation of privacy protection measures must have high priority.

In our future work, we plan to design a service architecture of mobile location services for the next generation mobile IP network based on IPv6. We believe, that the mobile core network will change to be IP-based, and this could pave the way for worldwide location services. 


\section{REFERENCES}

[1] Mobile location services, Nokia white paper, 2001. Availablc: lutp://www.nokia.comidownloads/ahoutnokia/press/gdt/mlbs.pdf fcited $18 \mathrm{Feb} .2003]$.

[2] The UMTS Third Generation Market - Structuring the Service Revenue Opportunities. UMTS Forum, Report number 9, 2000. Available: lstp: $: /$ wwow umts-

forum.orniscrvietidveoniztumtsinnts/Livcioniumts/Resources Reports 09 index [cited $18 \mathrm{Fcb} .2003$ ].

[3] $3 G$ \& Bluetooth: Hot Spots For Opportunities. White paper, Widcomm Inc., 2001. Available:

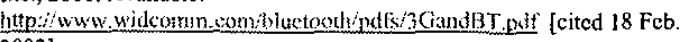
2002].

[4] Bluetooth Specification version 1.1. Bluetooth SIG, Inc., 2000.

Available:
https:/www bluctooth org: foundryspesification/documentspecitiction [itps: : / ww buluetoot

[5] P. Bhagwat, "Bluctooth: Technology for Short-Range Wireless Apps", IEEE Internet Computing, vol.5, no. 3, May-June 2001.

[6] M. Frodigh, P. Johansson, and P. Larsson, "Wireless ad hoc networking - The art of networking without a network". Ericsson Review, No. 4, 2000. Available:

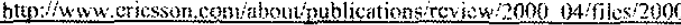
046.pdf [cited 18 Feb. 2003]

[7] IEEE 802.1/b High Rate Wireless Local Area Networks. White paper, Intel Corporation, 2000. Available:

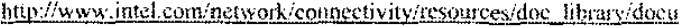
menisindfinpl692-01. pdr [cited 09 Sept. 2002] 